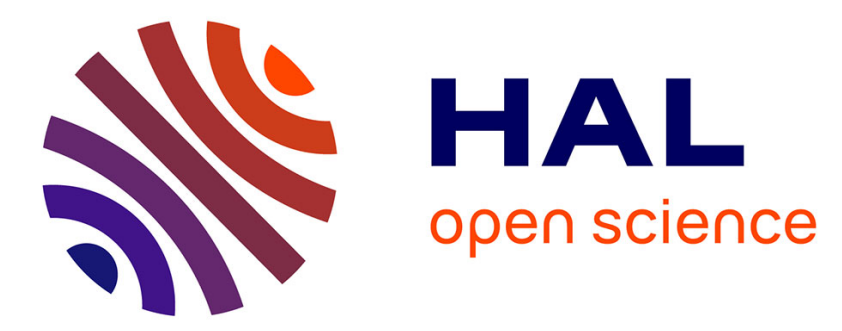

\title{
Effects of fire-induced water repellency on soil aggregate stability, splash erosion, and saturated hydraulic conductivity for different size fractions
}

Dennis Fox, F. Darboux, P. Carrega

\section{- To cite this version: \\ Dennis Fox, F. Darboux, P. Carrega. Effects of fire-induced water repellency on soil aggregate stability, splash erosion, and saturated hydraulic conductivity for different size fractions. At Process, 2007, 21, pp.2377 - 2384. hal-02572231}

\section{HAL Id: hal-02572231 \\ https://hal.science/hal-02572231}

Submitted on 6 Dec 2021

HAL is a multi-disciplinary open access archive for the deposit and dissemination of scientific research documents, whether they are published or not. The documents may come from teaching and research institutions in France or abroad, or from public or private research centers.
L'archive ouverte pluridisciplinaire $\mathbf{H A L}$, est destinée au dépôt et à la diffusion de documents scientifiques de niveau recherche, publiés ou non, émanant des établissements d'enseignement et de recherche français ou étrangers, des laboratoires publics ou privés. 


\title{
Effects of fire-induced water repellency on soil aggregate stability, splash erosion, and saturated hydraulic conductivity for different size fractions
}

\author{
D. M. Fox, ${ }^{1 *}$ F. Darboux ${ }^{2}$ and P. Carrega ${ }^{1}$ \\ ${ }^{1}$ UMR 6012 CNRS, Department of Geography, University of Nice Sophia Antipolis, 98 Blvd. Ed. Herriot, BP 3209, 06204 Nice cedex 3, France \\ ${ }^{2}$ INRA Orléans-Science du Sol, Av. de la Pomme de Pin, BP 20619, F-45166 Olivet Cedex, France. Frederic
}

\begin{abstract}
:
Forest fires can alter several soil properties influencing soil erosion and runoff processes in addition to removing all or part of the vegetative cover. These include organic matter content, aggregate stability and water repellency. Soil erodibility and saturated hydraulic conductivity depend on these properties and their response varies according to aggregate size. The objective of the study was to investigate how forest fires affect key soil properties and determine the potential impact of these on runoff and erosion processes. The A horizon of an acidic sandy loam was collected and subjected to a pine litter fire. The burned and control soil samples were separated into 4 size fractions: bulk $(<5 \cdot 0 \mathrm{~mm}),<0 \cdot 4,0 \cdot 4-2 \cdot 0$, and 2.0-5.0 mm. Organic matter (OM), aggregate stability mean weight diameter (MWD), and water drop penetration time (WDPT) were measured for each size class. Each size fraction sample was subjected to $0.5 \mathrm{~h}$ of simulated rainfall $\left(55 \mathrm{~mm} \mathrm{~h}^{-1}\right)$ for splash erosion measurements. Saturated hydraulic conductivity (K) measurements were performed on the same samples. Burning the litter decreased soil OM content but increased MWD and WDPT. Splash erosion increased greatly for the bulk and $<0.4 \mathrm{~mm}$ samples. MWD increased for the 0.4-2.0 and 2.0-5.0 mm size fractions despite a loss in OM and clay content in the burned soil. A surface crust never formed on the water repellent fine fraction leaving plenty of non-cohesive material available for soil detachment. Increased water repellency reduced $\mathrm{K}$ for all size fractions. The data support the need for a specific soil erodibility index for post-forest fire soils. Copyright (c) 2007 John Wiley \& Sons, Ltd.
\end{abstract}

KEY WORDS forest fire; soil erosion; saturated hydraulic conductivity; aggregate stability; water repellency

Received 15 December 2005; Accepted 9 August 2006

\section{INTRODUCTION}

The increases in runoff and soil erosion rates observed after a forest fire are due primarily to the destruction of the vegetation cover (Prosser and Williams, 1998; Johansen et al., 2001; Wohlgemuth et al., 2001). In addition, the combustion of the standing vegetation and litter layer provokes several changes in soil properties. The study of low severity fires or traditional slash and burn methods has confirmed some of the short-term benefits of forest fires on soil fertility $(\mathrm{pH}$, nutrient status) and their influence on post-fire re-growth (Soto et al., 1995; Neary et al., 1999). However, the effects are not all beneficial since combustion of soil organic matter $(\mathrm{OM})$ can also lead to lower cation exchange capacities, and high severity fires can lead to significant nutrient losses through volatilization and accelerated erosion (Martin et al., 1998; Neary et al., 1999; Thomas et al., 1999). Two further changes in soil characteristics, the development or enhancement of water repellency and a decrease in aggregate stability, have a direct impact on soil erodibility (Andreu et al., 2001).

\footnotetext{
* Correspondence to: D. M. Fox, UMR 6012 CNRS, Department of Geography, University of Nice Sophia Antipolis, 98 Blvd. Ed. Herriot,
} BP 3209, 06204 Nice cedex 3, France. E-mail: fox@unice.fr
The formation of soil water repellency, or hydrophobicity, has been described extensively elsewhere (Wallis and Horne, 1992; DeBano, 2000a, b; Doerr et al., 2000; Harper et al., 2000; Huffman et al., 2001), so only a few aspects related directly to runoff generation and soil erosion will be considered here. Water repellency develops naturally in many forests, particularly in sandy acid, but also alkaline soils with pine vegetation (Buczko et al., 2002; Doerr et al., 1998; Mataix-Solera and Doerr, 2004; Cerdà and Doerr, 2007). During a forest fire, heat from combustion vapourizes organic substances that migrate downwards into the soil where they condense at cooler temperatures and coat mineral particles (DeBano, 2000a). At temperatures below about $175^{\circ} \mathrm{C}$, there is little or no change in water repellency; temperatures between about 175 and $280^{\circ} \mathrm{C}$ increase water repellency; and temperatures above $280^{\circ} \mathrm{C}$ tend to destroy it (DeBano, 2000a; Doerr et al., 2004). After a forest fire, it is therefore common to find patches of water repellent soil at or close to the surface (DeBano, 2000a; Mataix-Solera and Doerr, 2004).

The presence of a water repellent layer alters the usual processes associated with runoff and erosion. Contrary to most natural soils, the infiltration rate for water repellent soils is lowest initially when the soil is dry and increases as the aggregates are wetted (DeBano, 2000a). Runoff 
can therefore be initiated in the first minutes of a rainfall event. For splash erosion, water repellent coatings on the minerals at the surface may inhibit the formation of a soil crust, so surface material is more easily detached by raindrop impact (Terry and Shakesby, 1993). As for rill erosion, the presence of a water repellent layer at depth induces a pore pressure build-up and corresponding decrease in shear strength in the overlying saturated soil, so rill erosion is facilitated; if the rills cut through the water repellent layer, then infiltration can increase and change the infiltration-runoff balance (DeBano, 2000b). Where forest soils are naturally extremely water repellent, there is little difference between pre-fire and postfire water repellency, though both situations are much more water repellent than neighbouring cultivated soils (Doerr et al., 1998; Shakesby et al., 2000). Water repellency tends to decrease in the months following a forest fire to reach pre-fire levels within up to about 6 years (Huffman et al., 2001).

The impact of forest fires on soil aggregate stability is more ambiguous than for water repellency. On the one hand, forest fires tend to produce greater water repellency in most forest soils and this tends to reduce slaking. Slaking results from a build-up in pore pressure in aggregates as water is drawn into the aggregate by attractive forces known as matric suction. Since water repellent coatings alter the attractive force between water and particle surfaces, matric suction decreases or disappears, increasing aggregate stability (Mataix-Solera and Doerr, 2004). On the other hand, aggregate stability is positively correlated with organic matter content, in the form of both transitory polysaccharides and more stable humus, so the destruction of organic compounds present in the soil tends to decrease aggregate stability (Cerdà et al., 1995; Giovannini et al., 2001). The net effect probably depends on initial organic matter content, soil texture, fire intensity, and the size range of aggregates being considered. Mataix-Solera and Doerr (2004) showed that finer size fractions $(<0.25 \mathrm{~mm})$ are more water repellent than larger ones, and that both water repellency and aggregate stability are correlated with soil organic matter for different size fractions. Considering the interactions between water repellency, aggregate stability, infiltration and erosion, this question requires further research.

The objective of this study was to evaluate the impact of a pine needle fire on soil organic matter, aggregate stability, and water repellency, and to estimate the consequences of these changes on splash erosion and saturated hydraulic conductivity for the bulk soil and different size fractions.

\section{MATERIALS AND METHODS}

\section{General experimental procedure}

A sample of soil was collected from the A horizon of an acid truncated planosol (Baize and Girard, 1995; FAO/ISRIC/ISSS, 1998) and transported to a laboratory where it was air dried and sieved to retain the $<5 \mathrm{~mm}$ fraction. This was separated into two bulk samples, one of which was subjected to a pine needle fire. Bulk samples of both the control and burned soils were set aside and the remaining soil was sieved into the following fractions: $<0.4 \mathrm{~mm}$ (Fine), $0.4-2.0 \mathrm{~mm}$ (Medium), and $2.0-5.0 \mathrm{~mm}$ (Coarse). Soil organic matter, aggregate stability, and water repellency were quantified for the bulk soil and each of the size fractions. Rainfall simulations were then performed to estimate splash erosion and the same samples were subsequently used for saturated hydraulic conductivity measurements. The details of the procedure are described below according to the type of variable analysed. Soil properties, describes the properties of the burned and control soils that will be used as explanatory variables. Rainfall simulations and saturated hydraulic conductivity, describes the variables, splash erosion rate and saturated hydraulic conductivity, influenced by the changes in soil properties.

\section{The fire treatment and measurement of soil properties}

The soil collected for the experiment was a sandy loam (Soil Survey Division Staff, 1993) located on a plain with a pine forest cover near Orleans (France). Initial soil properties were the following: OM content $4.4 \%$, and clay, silt and sand contents of 8,26 , and $66 \%$, respectively. A total disturbed sample of approximately $100 \mathrm{~kg}$ was collected and separated into two sub-samples, hereafter called the 'burned' and 'control' soils or samples. The burned soil was laid on a plate metal sheet to a depth of about $4 \mathrm{~cm}$ and a thermocouple was inserted in the soil to a depth of $2 \mathrm{~cm}$. It displayed instantaneous readings of temperature. A layer of dried pine needles collected from the sample site was applied to the surface and set alight. Pine needles were added to the surface until the temperature at $2 \mathrm{~cm}$ reached $150^{\circ} \mathrm{C}$. Fixing a threshold of $150^{\circ} \mathrm{C}$ within the soil ensured that temperature conditions within the upper layer $\left(\geq 150^{\circ} \mathrm{C}\right)$ of the soil would be conducive to the development of water repellency.

After the fire, bulk samples of both the burned and control soils were set aside and the remainder of the soil was gently hand sieved to the following sizes: $<0.4,0.4-2.0$, and $2.0-5.0 \mathrm{~mm}$. For each sample, clay content and $\mathrm{OM}$ (loss on ignition: $600{ }^{\circ} \mathrm{C}$ during $5 \mathrm{~h}$ ) were determined. There were no replicate measurements for these two properties. The bulk soil and each of the size fractions were packed into $5.5 \mathrm{~cm}$ (length) $\times 6 \mathrm{~cm}$ (diameter) cylinders. The bottom of the cylinders was perforated to allow free drainage and circulation of air. Five replicates of each sub-sample were prepared giving a total sample size of 40 individuals: two fire treatments (burned and control), 4 size fractions (bulk, $<0.4,0.4-2.0$, and $2.0-5.0 \mathrm{~mm}$ ), and five replicates.

Aggregate stability was determined for $<0.4,0 \cdot 4-2 \cdot 0$, and $2 \cdot 0-5.0 \mathrm{~mm}$ samples using the fast wetting test of Le Bissonnais (1996). This method tests soil sensitivity to slaking. A $2 \mathrm{~g}$ soil sample, initially dried at $40^{\circ} \mathrm{C}$, is immersed in $50 \mathrm{ml}$ of deionized water. After $10 \mathrm{~min}$, the 
water is sucked up with a pipette. The soil fragments are transferred to a $0.500-\mathrm{mm}$ sieve immersed in ethanol. The $>0.500 \mathrm{~mm}$ fraction is air-dried and its size distribution measured by dried sieving. The size distribution of the $<0.500 \mathrm{~mm}$ fraction is measured using a laser-diffraction particle sizer. The mean weight diameter (MWD) of the complete fragment size distribution is computed. The test was replicated three times. Our study involves samples with three initial sizes and these samples could potentially have had different dispersed size distributions. Both initial size distribution (particles + aggregates) and dispersed size distribution (particles only) of a sample can affect its MWD during fast wetting. To facilitate aggregate stability comparison, the fast wetting MWD was normalized with the MWD of the initial sample and with the MWD of its dispersed size distribution. The resulting aggregate stability index is expressed as a percentage:

$$
\frac{M W D(\text { after fast wetting })-M W D(\text { dispersed })}{M W D(\text { initial })-M W D(\text { dispersed })} \times 100
$$

The closer the ratio is to $100 \%$, the greater the aggregate stability of the sample, independently of its dispersed and initial size distributions. A value of $100 \%$ means the fast wetting caused no disaggregation.

Water repellency was measured using the water drop penetration time (WDPT) method described in Bisdom et al. (1993). The WDPT method is a measure of the time required for a water drop to penetrate the surface of a soil. In our case, cylinders of $1.5 \mathrm{~cm}$ (length) $\times$ $5 \mathrm{~cm}$ (diameter) were packed by adding soil and tapping lightly; they were then allowed to sit for $3 \mathrm{~h}$ to avoid differences in WDPT values due to air temperature or relative humidity. On each soil cylinder surface, five water drops of $22.9 \mu \mathrm{l}$ each (std. dev. $=3.6 \mu \mathrm{l}$ ) were applied to the surface and the penetration time measured using a stopwatch. For each sub-sample, three replicate cylinders were included, so final mean penetration time was the average of 15 drops (there were no significant differences between cylinders of the same sub-sample).

\section{Rainfall simulations and saturated hydraulic conductivity measurements}

Samples packed in the $5.5 \mathrm{~cm}$ (length) $\times 6 \mathrm{~cm}$ (diameter) cylinders were subjected to $30 \mathrm{~min}$ of rainfall at a mean intensity of $55.8 \mathrm{~mm} \mathrm{~h}^{-1}$ (std. dev. $=$ $1.13 \mathrm{~mm} \mathrm{~h}^{-1}$ ). Mean drop size diameter was $1.4 \mathrm{~mm}$ (kinetic energy $=13 \mathrm{~J} \mathrm{~mm}^{-1} \mathrm{~m}^{-2}$ ). The soil sample was inserted within a larger collector cylinder placed on a rotating base. A total of 10 cylinders were included on the base, so 10 samples could be run simultaneously during a single rainfall simulation. The samples were ordered randomly, and spatial differences in rainfall intensity were corrected by gently rotating the base during the simulation. Collector cylinders were used as rain gauges to measure rain intensity for each sample. These values were used as covariates in the analysis of variance on splash erosion but differences in rainfall intensity were not significantly different. At the end of the rainfall simulation, water and sediments collected within the larger collector cylinders were placed in an oven at $105^{\circ} \mathrm{C}$ to evaporate water and quantify total erosion due to splash (g).

The cylinders used for the splash erosion rates were also used for saturated hydraulic conductivity (K) measurements. After clamping the cylinder in an appropriate holder, the sample was inverted and water input was from below to allow free circulation of air. A head of $2 \mathrm{~cm}$ was applied and cumulative output was measured at $1 \mathrm{~min}$ intervals on a balance connected to an automated recording device. For each sample, three replicate measurements were performed giving a total sample size of 24 observations ( 2 fire treatments $\times 4$ size fraction $\times 3$ replicates).

\section{Statistical analysis}

The measured soil properties were the following: soil organic matter $(\%)$, clay content $(\%)$, water repellency $(\mathrm{s})$, aggregate stability (\%), splash erosion (g), and saturated hydraulic conductivity $\left(\mathrm{mm} \mathrm{h}^{-1}\right)$. Values were obtained for each of the two fire treatments (burned, control) and four size classes (bulk, <0.4, 0.4-2.0 and $2.0-5.0 \mathrm{~mm}$ ). The number of replicates varied from three to five except for soil organic matter and clay content. A classic analysis of variance was performed to test for significant differences $(P \leq 0 \cdot 05)$ due to the two experimental factors (fire treatment and size class) and their interaction (fire treatment $\times$ size class). In addition, Pearson correlations were performed on the mean values of the variables for the fine $(<0.4 \mathrm{~mm})$, medium $(0.4-2.0 \mathrm{~mm})$ and coarse $(2.0-5.0 \mathrm{~mm})$ size fractions. There were only six values for these correlations ( 2 fire treatments $\times 3$ size fractions), so, significance tests were not performed, and only values of $r>0.7$ or $r<-0.7$ will be cited.

\section{RESULTS}

Initial size fraction distribution for the soil was the following: $50 \%<0.4 \mathrm{~mm}, 30 \% \quad 0.4-2.0 \mathrm{~mm}$, and $20 \%$ $2 \cdot 0-5.0 \mathrm{~mm}$. For the burned soil, the size fraction distribution was $40 \%<0.4 \mathrm{~mm}, 32 \% \quad 0.4-2.0 \mathrm{~mm}$, and $28 \%$ $2.0-5.0 \mathrm{~mm}$. Since the $<0.4 \mathrm{~mm}$ size fraction is the most important, the trends in the following results for the bulk sample tend to follow those of the fine $(<0.4 \mathrm{~mm})$ fraction. The results will be presented in two sub-sections. In the first, changes in soil OM, water repellency and aggregate stability will be considered. In the second, differences in splash erosion and saturated hydraulic conductivity will be described. The results will then be followed by an analysis of the findings in the discussion section.

\section{Changes in soil properties}

OM decreased in the burned soil for all size fractions. The greatest difference $(0.43 \%)$ occurred in the $<0.4 \mathrm{~mm}$ fraction where OM contents were greatest (Figure 1). The trend, however, is not progressive with increasing size fraction and the lowest contents (about 3.4\%) and 


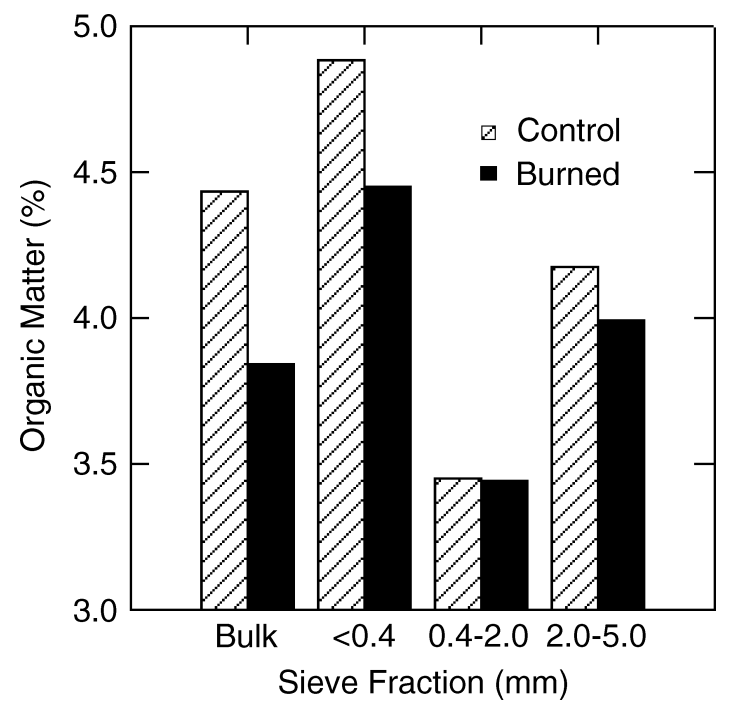

Figure 1. Soil organic matter decreased in the burned soil for all size fractions

difference $(0.01 \%)$ were observed in the intermediate $(0.4-2.0 \mathrm{~mm})$ fraction. Detailed analyses of OM type were not carried out, but it is probable that the OM in the $<0.4 \mathrm{~mm}$ fraction is made up essentially of humus, whereas the $\mathrm{OM}$ in the coarser $2.0-5.0 \mathrm{~mm}$ fraction is comprised of a combination of humus and free organic debris. Humus is made of large amorphous colloids that contribute directly to aggregate stability through their electrostatic charge (Brady and Weil, 1999). The increase in $\mathrm{OM}$ between the $0.4-2.0 \mathrm{~mm}$ and $2.0-5.0 \mathrm{~mm}$ size fractions is probably due to greater free organic debris (fragments of roots, leaves and stems), and these have little impact on aggregate stability.

There is no apparent relationship between aggregate stability (Figure 2) and OM for the burned and control soils (the correlation coefficient is less 0.7 and not statistically significant). OM can strongly influence aggregate stability (Oades, 1984; Mataix-Solera and Doerr, 2004), but the range in values in this experiment was narrow (from 3.44 to $4.45 \%$ for the burned soil and 3.44-4.88\% for the control). In addition, the impact of OM on aggregate stability depends on OM type, and it is likely that this varied for the different size fractions considered.

The fire treatment affected MWD differently for different size fractions. The $<0.4 \mathrm{~mm}$ fraction showed a net decrease in aggregate stability (Figure 2). This result contradicts the findings of Fernández et al. (2005) and is difficult to explain. For the coarser fractions $(0.4-2 \cdot 0$ and $2.0-5.0 \mathrm{~mm}$ ) the difference in aggregate stability between the control and burned soils increased with size fraction. For both the control and burned soils, MWD was lowest for the $<0.4 \mathrm{~mm}$ fraction. The $0.4-2.0$ and $2.0-5.0 \mathrm{~mm}$ classes had similar values. In the analysis of variance, fire treatment, size fraction, and the fire treatment $\times$ size fraction interaction were all statistically significant $(P \leq 0.05)\left(r^{2}=0.91\right)$. Hence, aggregate stability changed with fire treatment and size class and the direction of change (increase or decrease in aggregate stability) with the fire treatment was size class sensitive: the

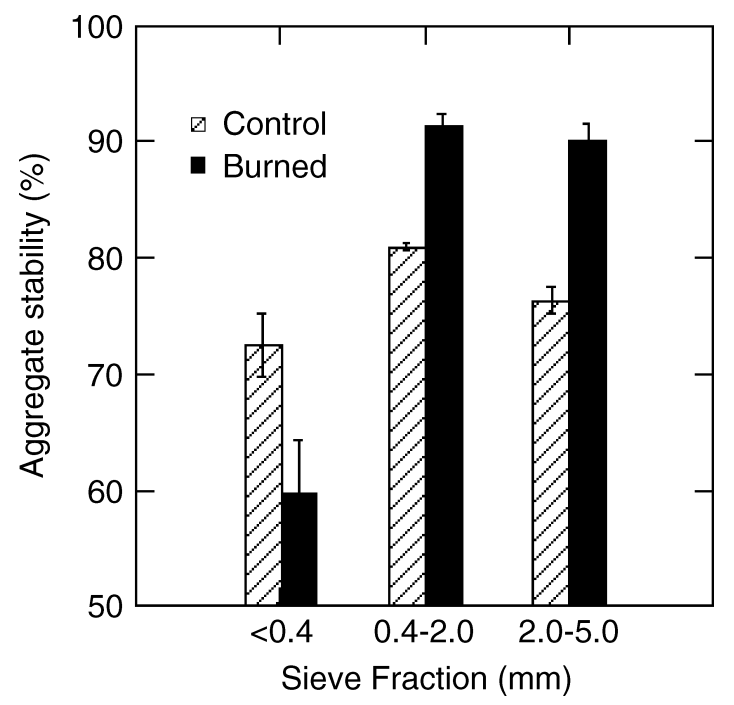

Figure 2. Aggregate stability varied according to size fraction. For the $<0.4 \mathrm{~mm}$ fraction, aggregate stability was greater for the control, but for the coarser fractions it was greater for the burned soil

intermediate and coarse fractions showed a net increase in aggregate stability, the fine fraction lost in aggregate stability (Figure 2).

In the absence of a clear relationship between OM and MWD, clay content was considered a potential factor affecting stability. Clay content increased with increasing aggregate size for both the control and burned soils (Figure 3). The increase in clay content is consistent with the formation of larger aggregates able to withstand the sieving process that initially separated the soil into separate size fractions.

Soils under natural vegetation can display some water repellency even in the absence of a forest fire (Barrett and Slaymaker, 1989; Doerr et al., 1998; Shakesby et al., 2000; Doerr et al., 2006). The bulk soil had an initial mean WDPT of about $10 \mathrm{~s}$ (Figure 4). The arbitrary limit between hydrophilic and water repellent soils is set

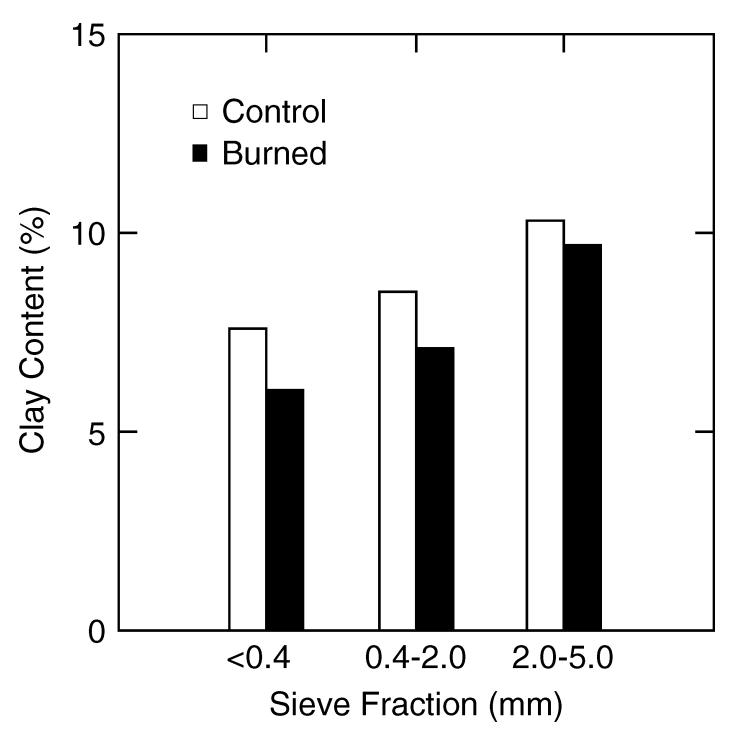

Figure 3. Clay content increased with increasing size fraction, and burning the soil reduced the clay content for all size fractions 


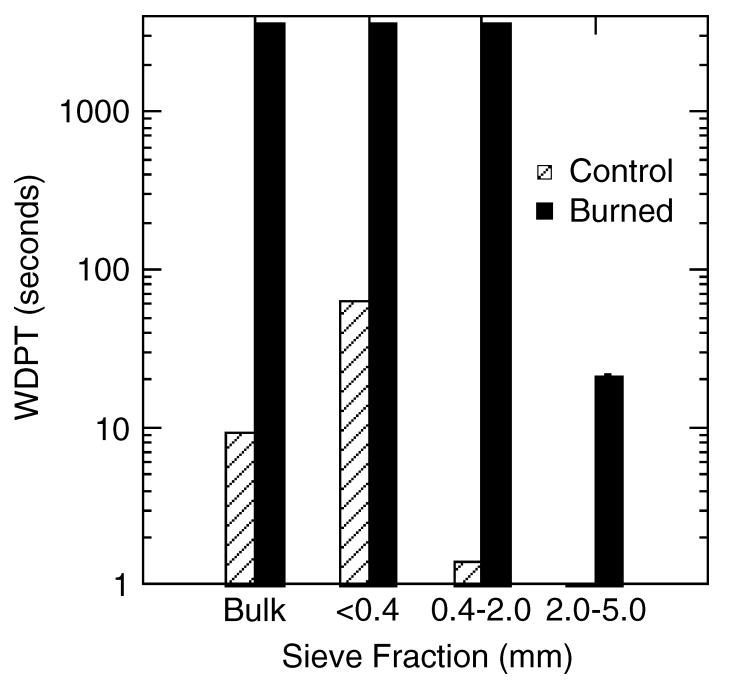

Figure 4. The initial forest soil (control-bulk) was already water repellent before the fire treatment. The pine needle litter fire dramatically increased WDPT for all size fractions

at about $5 \mathrm{~s}$ (Bisdom et al., 1993). As expected, WDPT increased due to the fire treatment (Figure 4). In addition, WDPT was greater for the finer size fractions $(<2.0 \mathrm{~mm})$, as has been observed by others (Bisdom et al., 1993; Mataix-Solera and Doerr, 2004). For the control soil, the $0.4-2.0$ and $2 \cdot 0-5.0 \mathrm{~mm}$ fractions were hydrophilic. After burning, water repellency increased dramatically for the bulk, fine and intermediate size classes and substantially for the coarse fraction. The trends shown in Figure 4 were statistically significant $(P \leq 0.05)$ in the analysis of variance for fire treatment, size fraction, and the fire treatment $\times$ size fraction interaction $\left(r^{2}=0.99\right)$. The burned soil had significantly greater WDPT values, and WDPT decreased with increasing size fraction. The interaction term (fire treatment $\times$ size fraction) was significant due to the relatively smaller increase in water repellency for the $2 \cdot 0-5.0 \mathrm{~mm}$ fraction compared to the others.

\section{Splash erosion and saturated hydraulic conductivity}

Splash erosion varied according to both fire treatment and size fraction (Figure 5). Fire treatment effect was greatest for the fine fraction and decreased with increasing aggregate size. The burned soil had much greater splash erosion values than the control in the $<0.4 \mathrm{~mm}$ size fraction. Values were similar in the $0.4-2.0 \mathrm{~mm}$ range. The control sample had greater erosion rates than the burned soil in the $2 \cdot 0-5.0 \mathrm{~mm}$ fraction.

Splash erosion was greatest for the fine $(<0.4 \mathrm{~mm})$ size fraction and decreased progressively with increasing size class. Splash erosion is known to be size selective (Ellison, 1944; Legout et al., 2005). Size selection depends on both rainfall characteristics, which determine the largest fraction that can be moved, and soil properties, which determine the size distribution available for transport. Fine to intermediate fractions $(0 \cdot 1-1.0 \mathrm{~mm})$ are the most susceptible to the splash process (Poesen and Savat, 1980; Legout et al., 2005). This is consistent with

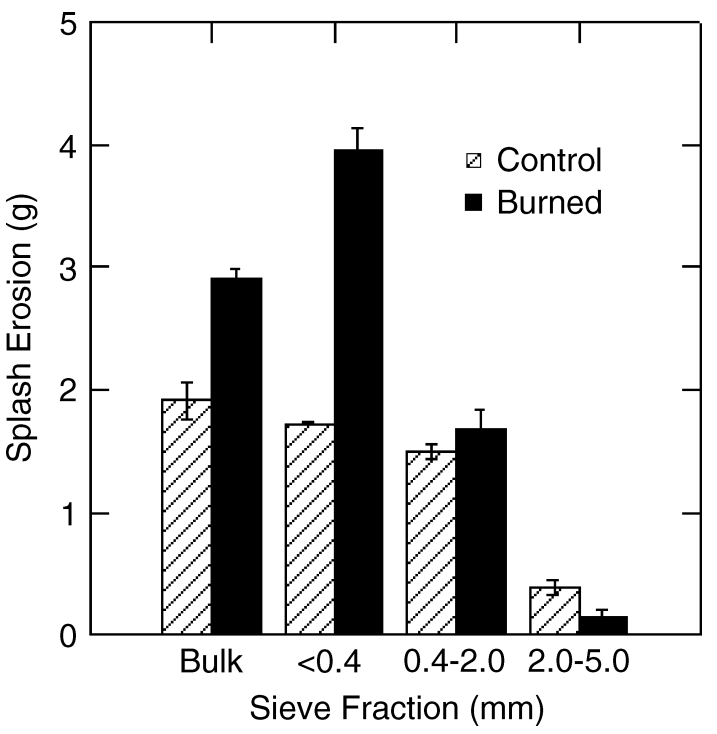

Figure 5. The impact of fire treatment on splash erosion varied according to initial size fraction: the burned soil had greater erosion than the control in the fine fraction, and the reverse occurred in the coarse fraction. Rates in the intermediate range were similar

the splash erosion results presented here which show a peak in the fine fraction with a progressive decrease with aggregate size. The analysis of variance testing trends in Figure 5 showed that fire treatment, size fraction, and the fire treatment $\times$ size interaction were all statistically significant $(P \leq 0.05)\left(r^{2}=0.96\right)$. Splash erosion was negatively correlated with clay content $(r=-0.92)$, MWD $(r=-0.73)$ and $\mathrm{K}(r=-0.82)$ which is consistent with expectations.

Saturated hydraulic conductivity measurements were carried out until a final constant rate was attained. This occurred more quickly for the coarsest size fraction $(2 \cdot 0-5.0 \mathrm{~mm})$, and time duration for these samples was approximately $3 \mathrm{~h}$. The fine fraction $(<0.4 \mathrm{~mm})$ was the longest to attain hydraulic equilibrium and these samples were measured over a period of about $24 \mathrm{~h}$. The burned $<0.4 \mathrm{~mm}$ fraction was left for up to $48 \mathrm{~h}$ without ever providing any outflow due to its extreme water repellency. Saturated hydraulic conductivity $(\mathrm{K})$ increased with increasing size fraction (Figure 6). As aggregates get larger, mean pore size increases with a corresponding decrease in resistance to flow. Hydraulic conductivities for the fine $(<0.4 \mathrm{~mm})$ and bulk control samples were less than $5 \mathrm{~mm} \mathrm{~h}^{-1}$. After burning, these soils became highly impermeable and the wetting front in the cylinders had penetrated to only a few $\mathrm{mm}$ after $48 \mathrm{~h}$ of ponding with a $2-\mathrm{cm}$ head. Changes in $\mathrm{K}$ with burning for the coarser fractions $(0.4-2.0$ and $2.0-5.0 \mathrm{~mm})$ were substantial but less dramatic. $\mathrm{K}$ decreased by about 37 and $23 \%$ for the $0.4-2.0$ and $2 \cdot 0-5.0 \mathrm{~mm}$ size fractions, respectively. These changes in $\mathrm{K}$ are consistent with values cited by Robichaud (2000) who found that post-fire saturated hydraulic conductivity values were $0 \cdot 1-0.4$ the normal rates measured using field rainfall simulations. Fire treatment and size fraction had a statistically significant $(P \leq 0.05)$ impact on $\mathrm{K}\left(r^{2}=0.91\right)$. In 


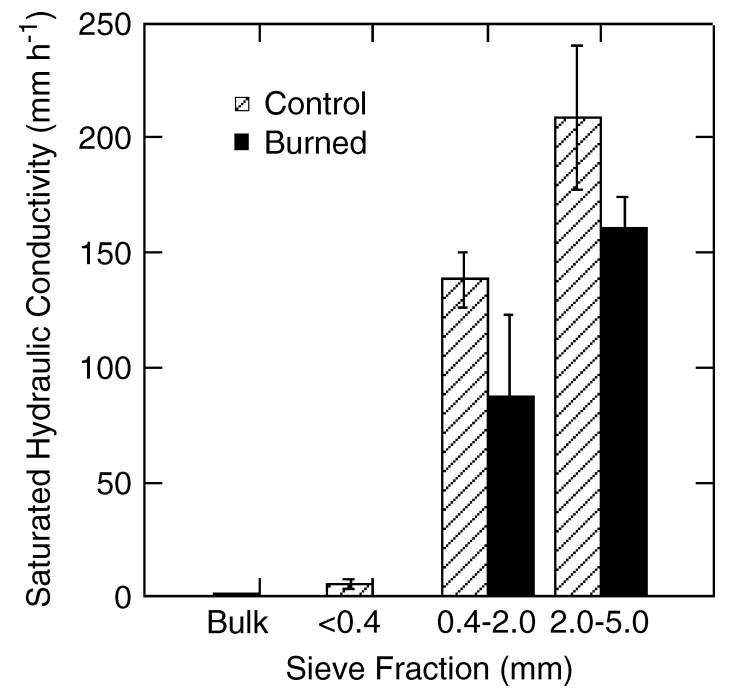

Figure 6. Saturated hydraulic conductivity values increased with increasing size fraction and post-fire values were lower than the control soil

addition, $\mathrm{K}$ was negatively correlated with $\log _{10}$ WDPT $(r=-0.73)$.

\section{DISCUSSION}

The experimental design was initially set up to ensure that water repellent conditions would be created during burning. Hence, soil properties (acid sandy loam), forest cover (pine), litter material (dried pine needles), and fire intensity (soil temperatures in the top $2 \mathrm{~cm} \geq 150^{\circ} \mathrm{C}$ ) were all selected according to trends cited in the literature with this objective (Wallis and Horne, 1992; DeBano, 2000a; Doerr et al., 2000; DeBano, 2000b; Huffman et al., 2001). Extreme water repellency was generated in the burned soil. Clear differences arose between fire treatments and size classes that deserve further discussion.

Clay content values for the burned soil decreased by $20 \cdot 7,17.1$ and $6 \%$ for the $<0.4,0.4-2.0$ and $2.0-5.0 \mathrm{~mm}$ size fractions, respectively (Figure 3). A decrease in clay content of about 40 to $65 \%$ has been observed by others (Fernández et al., 2005; Hubbert et al., 2006). High-intensity fires generating soil temperatures above about $300^{\circ} \mathrm{C}$ increase the silt and fine sand contents as smaller clay particles are cemented together (Giovannini et al., 2001). Surface temperatures were not measured in our experiment but it is assumed that cementation of clay particles may be responsible for the decrease in clay content shown in Figure 3. Normally, these changes would be expected to decrease aggregate stability as the clay fraction decreases and is converted into silt or fine sand-sized aggregates. However, this is clearly not the case, as MWD (Figure 2) increased despite a decrease in clay content (Figure 3).

Aggregate stability increased for the $0.4-2.0$ and $2.0-5.0 \mathrm{~mm}$ size fractions despite losses in both $\mathrm{OM}$ and clay content, two factors which normally contribute to greater MWD values. These findings should not be contrasted with other studies showing increases in aggregate stability with either OM (Chenu et al., 2000; Mataix-Solera and Doerr, 2004) or clay content (Kemper et al., 1987; Lado et al., 2004). In our case, the same soil underwent relatively small changes in $\mathrm{OM}$ and clay content during the fire, and water repellency appears to have become the dominant factor controlling aggregate stability. Aggregate stability has been shown to be sensitive to the water-solid contact angle where stability decreases with decreasing contact angle (less water repellent), so greater aggregate stability for the more water repellent burned soil is consistent with the finding of Ellies et al. (2005).

There remains some ambiguity about the interactions between water repellency, aggregate stability, and size fraction. The $0.4-2.0 \mathrm{~mm}$ and $2 \cdot 0-5.0 \mathrm{~mm}$ fractions behaved as hypothesized with a net increase in MWD. These results are consistent with the findings of others working on similar size fractions (MataixSolera and Doerr, 2004; Fernández et al., 2005). The fine fraction $(<0.4 \mathrm{~mm})$ decreased in aggregate stability, and although this corresponds well with the splash erosion values which were negatively correlated with MWD $(r=-0.73)$, it is difficult to explain why aggregate stability would decrease for only the fine size fraction $(<0.4 \mathrm{~mm})$ and not the others $(0.4-2.0 \mathrm{~mm}$ and $2 \cdot 0-5.0 \mathrm{~mm}$ ). This requires further investigation. The results, however, clearly demonstrate the impact of changes on the bulk soil according to the changes in the dominant size fraction. In our case, the $<0.4 \mathrm{~mm}$ fraction made up about $50 \%$ of the bulk soil and changes in water repellency in this fraction dominated splash erosion and hydraulic behaviour of the soil compared to the other size fractions.

Contradictory findings concerning the relationship between water repellency and texture cited by MataixSolera and Doerr (2004) may arise partly from a confusion between the effects of soil texture and structure. Soil texture is the size distribution of dispersed mineral particles, whereas soil structure depends on the grouping of soil particles into aggregates or peds (Brady and Weil, 1999). Finer size fractions made up of both aggregates and individual particles appear to be more sensitive to water repellency, but this does not necessarily mean that fine textured soils are more water repellent. In this study, the coarsest size fractions also had the greatest clay contents, so fine size fractions should not be associated with fine textured soils, nor should coarse size fractions be compared to coarse textured soils. Possible mechanisms accounting for the relationships between soil texture, structure, and water repellency are described in detail in Mataix-Solera and Doerr (2004) and will not be taken up again here. In addition to these explanations, however, two further considerations can be forwarded. The first is that although water repellency is a phenomenon associated with the coating of individual particles (and not entire aggregates) and interstitial hydrophobic compounds (Bisdom et al., 1993), the measurement of water repellency using WDPT inevitably 
depends not only on the concentration of particle coatings but also on water drop size and inter-particle and inter-aggregate pore space diameters. Water repellency is created by hydrophobic organic compounds that modify the contact angle between water and the mineral surface. WDPT depends on both this contact and the mean wetting angle resulting from the relative proportions of water in contact with the mineral surface and air (Bachmann et al., 2000). Hence, different size fractions may have identical hydrophobic compound concentrations on the mineral surfaces but lower WDPT values for coarser size fractions due to the greater proportion of water in contact with air and not the water repellent mineral surface. In our study, hydrophobic compound concentrations were not measured, so it is impossible to determine whether the lower WDPT and greater $\mathrm{K}$ values found for the coarsest $(2.0-5.0 \mathrm{~mm})$ fraction were due to lower hydrophobic compound concentrations or a lower mineral surface-toair water contact ratio.

Splash erosion results were also size fraction sensitive. In this case, different dominant processes can be attributed to different size fractions. In the finest fraction $(<0.4 \mathrm{~mm})$, splash erosion is controlled by changes in surface resistance to detachment associated with soil crusting. As noted above, in a hydrophilic soil, crusting forms a dense layer that reduces splash detachment (Fox and Bryan, 1999). In the water repellent soil, the surface never formed cohesive bonds and the small non-cohesive individual particles and aggregates were easily detached by raindrop impact. This process was clearly demonstrated for water repellent soils by Terry and Shakesby (1993). Splash erosion rates measured by Terry and Shakesby (1993) on sieved soil samples $(<2.0 \mathrm{~mm})$ were significantly greater on the water repellent soil and, with the aid of video photography, the authors were able to demonstrate that water repellency inhibited crust formation. In the absence of crust formation, an abundance of easily mobilized sediments remain on the surface and splash erosion rates are high. Photographs of this process were not made in this study, but visual observations confirmed that the process filmed by Terry and Shakesby (1993) was responsible for the high erosion rates observed in the fine fraction.

For the coarsest fraction, neither the control nor the burned soil formed a surface crust. The lower splash erosion rates for the burned soil can be attributed directly to increased aggregate stability. The greater resistance of the burned aggregates to slaking results in lower erosion rates. In the finest fraction, the lack of inter-aggregate coalescence, and not individual aggregate stability, is the dominant process determining erosion whereas in the coarsest fraction, the inherent stability of aggregates is most important since even in the absence of surface crusting and inter-aggregate cohesion, individual intact aggregates remain too large to be detached and transported from the soil matrix by the kinetic energy of raindrops alone. It should be noted that better aggregate stability is usually associated with less crusting (Fox and Le Bissonnais, 1998), but for the $<0.4 \mathrm{~mm}$ fraction, crusting is dominated not by aggregate stability but by water repellency.

\section{CONCLUSIONS}

Forest fires destroy the vegetation cover and alter soil properties that influence runoff and erosion. In this study, the soil altered by fire behaved differently from pre-fire conditions. Water repellency affected aggregate stability, splash erosion, and saturated hydraulic conductivity, and the effect varied with size fraction. In the fine size fraction, water repellency was effective in inhibiting crust formation and this led to considerably greater splash erosion rates since surface cohesion remained low; in crusting soils, the increase in bulk density associated with crusting tends to reduce soil detachability. Splash erosion rates were also lower for the coarsest fraction but for a different reason. Water repellency reduces the matric suction forces responsible for slaking, and the lower erosion rates observed in the coarsest fraction of the fire-altered soil can be attributed to this. Increased aggregate stability was, therefore, directly related to reduced slaking. Saturated hydraulic conductivity decreased substantially with the development or enhancement of water repellency, and the effect was particularly pronounced for fine and intermediate sized aggregates. The effect of water repellency on hydraulic conductivity depends not only on the presence of hydrophobic compounds but also on the water : air and water: mineral surface contact areas. Research is currently underway to see how the relationships observed in this paper are altered by the presence of stones at the surface, and macro pores formed from the burning of plant roots.

\section{REFERENCES}

Andreu V, Imeson AC, Rubio JL. 2001. Temporal changes in soil aggregates and water erosion after a wildfire in a Mediterranean pine forest. Catena 44: 69-84, DOI: 10·1016/S0341-8162(00)00177-6.

Bachmann J, Ellies A, Hartge KH. 2000. Development and application of a new sessile drop contact angle method to assess soil water repellency. Journal of Hydrology 231-232: 66-75, DOI: 10.1016/S0022-1694(00)00184-0.

Baize D, Girard MC. (Coordinators). 1995. Référentiel pédologique. Institut National de la Recherche Agronomique and Association Française pour l'Étude du Sol: Paris; 324, ISBN: 2-7380-0633-7.

Barrett G, Slaymaker O. 1989. Identification, characterization, and hydrological implications of water repellency in mountain soils, Southern British Columbia. Catena 16: 477-489, DOI: 10·1016/03418162(89)90029-5.

Bisdom EBA, Dekker LW, Schoute JFTH. 1993. Water repellency of size fractions from sandy soils and relationships with organic material and soil structure. Geoderma 56: 105-118, DOI: 10·1016/00167061(93)90103-R.

Brady NC, Weil RR. 1999. The Nature and Properties of Soils., (12th edn). Prentice Hall: Upper Saddle River, NJ; 880, ISBN : 0-13852444-0.

Buczko U, Bens O, Fischer H, Hüttl RF. 2002. Water repellency in sandy luvisols under different forest transformation stages in northeast Germany. Geoderma 109: 1-18, DOI: 10.1016/S0016-7061(02) 00137-4.

Cerdà A, Doerr SH. 2007. Soil wettability, runoff and erodibility of major dry-Mediterranean land use types on calcareous soils. Hydrological Processes 21(17): 2325-2336.

Cerdà A, Imeson AC, Calvo A. 1995. Fire and aspect induced differences on the erodibility and hydrology of soils at La Costera, 
Valencia, Southeast Spain. Catena 24: 289-304, DOI: 10·1016/03418162(95)00031-2.

Chenu C, Le Bissonnais Y, Arrouays D. 2000. Organic matter influence on clay wettability and soil aggregate stability. Soil Science Society of America Journal 64: 1479-1486.

DeBano LF. 2000a. Water repellency in soils: a historical overview. Journal of Hydrology 231-232: 4-32, DOI: 10.1016/S00221694(00)00180-3.

DeBano LF. 2000b. The role of fire and soil heating on water repellency in wildland environments: a review. Journal of Hydrology 231-232: 195-206, DOI: 10·1016/S0022-1694(00)00194-3.

Doerr SH, Shakesby RA, Walsh RPD. 1998. Spatial variability of soil water repellency in fire-prone eucalyptus and pine forests, Portugal. Soil Science 163: 313-323.

Doerr SH, Shakesby RA, Walsh RPD. 2000. Soil water repellency: its causes, characteristics and hydro-geomorphological significance. Earth-Science Reviews 51: 33-65, DOI: 10.1016/S00128252(00)00011-8.

Doerr SH, Shakesby RA, Blake WH, Chafer CJ, Humphreys GS, Wallbrink PJ. 2006. Effects of differing wildfire severities on soil wettability and implications for hydrological response. Journal of Hydrology. 319: 295-311, DOI:10·1016/j.jhydrol.2005·06·038.

Doerr SH, Blake WH, Shakesby RA, Stagnitti F, Vuurens SH, Humphreys GS, Wallbrink P. 2004. Heating effects on water repellency in Australian eucalypt forest soils and their value in estimating wildfire soil temperatures. International Journal of Wildland Fire 13: 157-163, DOI: 10·1071/WF03051.

Ellies A, Ramírez C, Mac Donald R. 2005. Organic matter and wetting capacity distribution in aggregates of Chilean soils. Catena 59: 69-78, DOI: $10 \cdot 1016 /$ j.catena.2004.05.005.

Ellison WD. 1944. Studies of raindrop erosion. Agricultural Engineering 25: $131-136,181-182$

FAO/ISRIC/ISSS. 1998. World reference base for soil resources. World Soil Resources Report. No. 84, FAO: Rome; 88, ISSN: 0532-0488.

Fernández S, Marquínez J, Menéndez Duarte R. 2005. A susceptibility model for post wildfire soil erosion in a temperate oceanic mountain area of Spain. Catena 61: 256-272, DOI: 10.1016/j.catena.2005.03.006

Fox DM, Le Bissonnais Y. 1998. Process-based analysis of aggregate stability effects on sealing, infiltration, and interrill erosion. Soil Science Society of America Journal 62: 717-724.

Fox DM, Bryan RB. 1999. The relationship of soil loss by interrill erosion to slope gradient. Catena 38: 211-222, DOI: 10·1016/S03418162(99)00072-7.

Giovannini G, Vallejo R, Lucchesi S, Bautista S, Ciompi S, Llovet J. 2001. Effects of land use and eventual fire on soil erodibility in dry Mediterranean conditions. Forest Ecology and Management 147: 15-23, DOI: 10·1016/S0378-1127(00)00437-0.

Harper RJ, McKissock I, Gilkes RJ, Carter DJ, Blackwell PS. 2000. A multivariate framework for interpreting the effects of soil properties, soil management and landuse on water repellency. Journal of Hydrology 231-232: 371-383, DOI: 10·1016/S0022-1694(00)002092.

Hubbert KR, Preisler HK, Wohlgemuth PM, Graham RC, Narog MG. 2006. Prescribed burning effects on soil physical properties and soil water repellency in a steep chaparral watershed, southern California, USA. Geoderma 130: 284-298, DOI: 10·1016/j.geoderma.2005·02.001.

Huffman EL, MacDonald LH, Stednick JD. 2001. Strength and persistence of fire-induced soil hydrophobicity under ponderosa and lodgepole pine, Colorado front range. Hydrological Processes 15: 2877-2892, DOI: 10·1002/hyp.379.

Johansen MP, Hakonson TE, Breshears DD. 2001. Post-fire runoff and erosion from rainfall simulation: contrasting forests with shrublands and grasslands. Hydrological Processes 15: 2953-2965, DOI: 10·1002/hyp.384.
Kemper WD, Rosenau RC, Dexter AR. 1987. Cohesion development in disrupted soils as affected by clay and organic matter content and temperature. Soil Science Society of America Journal 51: 860-867.

Lado M, Ben-Hur M, Shainberg I. 2004. Soil wetting and texture effects on aggregate stability, seal formation, and erosion. Soil Science Society of America Journal 68: 1992-1999.

Le Bissonnais Y. 1996. Aggregate stability and assessment of soil crustability and erodibility: I. Theory and methodology. European Journal of Soil Science 47: 425-437, DOI: 10·1111/j.1365-2389.1996. tb01843.x.

Legout C, Leguédois S, Le Bissonnais Y, Malam Issa O. 2005. Splash distance and size distributions for various soils. Geoderma 124: 279-292, DOI: 10·1016/j.geoderma.2004·05·006.

Martin C, Chevalier Y, Gimenez H, Quillard J. 1998. Change of chemical composition of drainage and runoff waters and modification of soil agronomical characteristics after a forest fire in the Rimbaud catchment (Var, France) [in French]. Géomorphologie : Relief, Processus, Environnement 3: 215-232.

Mataix-Solera J, Doerr SH. 2004. Hydrophobicity and aggregate stability in calcareous topsoils from fire-affected pine forests in Southeastern Spain. Geoderma 118: 77-88, DOI: 10·1016/S0016-7061(03)00185$\mathrm{X}$.

Neary DG, Klopatek CC, DeBano LF, Ffolliott PF. 1999. Fire effects on belowground sustainability: a review and synthesis. Forest Ecology and Management 122: 51-71, DOI: 10·1016/S0378-1127(99)00032-8.

Oades JM. 1984. Soil organic matter and structural stability: mechanisms and implications for management. Plant and Soil 76: 319-337, DOI: 10.1007/BF02205590.

Pausas JG, Vallejo VR. 1999. The role of fire in European Mediterranean ecosystems. Remote Sensing of Large Wildfires in the European Mediterranean Basin, Chuvieco E (ed). Springer-Verlag: Berlin, 3-16.

Poesen J, Savat J. 1980. Particle-size separation during erosion by splash and runoff. Assessment of erosion, de Boodt M, Gabriels D (eds). Wiley: Chichester, UK; 427-439.

Prosser IP, Williams L. 1998. The effect of wildfire on runoff and erosion in native Eucalyptus forest. Hydrological Processes 12: 251-265, DOI: 10·1002/(SICI) 1099-1085(199802)12:2<251::AIDHYP574>3.0.CO $2-4$

Robichaud PR. 2000. Fire effects on infiltration rates after prescribed fire in Northern Rocky Mountain forests, USA. Journal of Hydrology 231-232: 220-229, DOI: 10·1016/S0022-1694(00)00196-7.

Shakesby RA, Doerr SH, Walsh RPD. 2000. The erosional impact of soil hydrophobicity: current problems and future research directions. Journal of Hydrology 231-232: 178-191, DOI: 10·1016/S00221694(00)00193-1.

Soil Survey Division Staff. 1993. Soil Survey Manual. Soil Conservation Service, United States Department of Agriculture: Washington, DC; Handbook 18.

Soto B, Basanta R, Perez R, Díaz-Fierros F. 1995. An experimental study of the influence of traditional slash-and-burn practices on soil erosion. Catena 24: 13-23, DOI: 10·1016/0341-8162(94)00030-I.

Terry JP, Shakesby RA. 1993. Soil hydrophobicity effects on rainsplash: simulated rainfall and photographic evidence. Earth Surface Processes and Landforms 18: 519-525.

Thomas AD, Walsh RPD, Shakesby RA. 1999. Nutrient losses in eroded sediment after fire in eucalyptus and pine forests in the wet Mediterranean environment of Northern Portugal. Catena 36: 283-302, DOI: 10·1016/S0341-8162(99)00051-X.

Wallis MG, Horne DJ. 1992. Soil water repellency. Advances in Soil Science, Stewart BA (ed). vol. 20, Springer: New York; 91-146.

Wohlgemuth PM, Hubbert KR, Robichaud PR. 2001. The effects of log erosion barriers on post-fire hydrologic response and sediment yield in small forested watersheds, Southern California. Hydrological Processes 15: 3053-3066, DOI: 0·1002/hyp.391. 